\title{
ANALISIS TIME SERIES METODE WINTER JUMLAH PENDERITA GASTROENTERITIS RAWAT INAP BERDASARKAN DATA REKAM MEDIS DI RSUD DR. SOETOMO SURABAYA
}

\author{
Sri Nawangwulan*, Dyan Angesti* \\ *Dosen Program Studi Rekam Medis dan Informasi Kesehatan (RMIK) \\ STIKES Yayasan Rumah Sakit Dr. Soetomo \\ surel: dyanangesti@gmail.com
}

\begin{abstract}
ABSTRAK
Masalah Gastroenteritis (GE) ialah masalah kesehatan masyarakat yang penanggulangannya tidak hanya dilakukan dengan pendekatan medis dan pelayanan kesehatan saja, melainkan dengan melakukan pemahaman tentang kebersihan makanan dan minuman yang akan dikonsumsi setiap harinya juga menyangkut aspek pengetahuan dan perilaku yang kurang mendukung pola hidup sehat.Analisis time series dan proyeksi tentang morbiditas bisa memberikan informasi yang berkaitan dengan angka kesakitan yang terjadi. Di RSUD Dr. Soetomo Surabaya jumlah penderita GE perbulan rata-rata mencapai 200 pasien. Dengan tingginya jumlah pasien GE tersebut, maka akan dilakukan analisis time series pada penderita GE di bagian unit rekam medis rawat inap RSUD Dr. Soetomo Surabaya berdasarkan data bulanan tahun 2011 sampai 2014, dilihat dari kejadian setiap bulannya. Hasil prediksi jumlah penderita $G E$ rawat inap bulan Mei 2014 terjadi peningkatan jumlah penderita menjadi 95 penderita; bulan Juni-Agustus terjadi penurunan jumlah penderita menjadi 80, 59, dan 16 penderita; September-November terjadi peningkatan menjadi 62, 103, dan 142 penderita; Mei-November 2014 Laki-laki mengalami peningkatan jumlah penderita pada bulan Mei sebanyak 54 penderita; bulan Juni-Agustus 2014 mengalami penurunan jumlah penderita menjadi 48, 38, dan 10 penderita; bulan SeptemberNovember 2014 mengalami peningkatan jumlah penderita sebanyak 29, 65, dan 83 penderita sebanyak di RSUD Dr. Soetomo.
\end{abstract}

Katakunci: Analisa Time Series, Gastroenteritis (GE), Rekam Medis

\section{ABSTRACT}

Gastroenteritis (GE) problems is a public health problem which able to overcome not only done with medical and health services approach alone, but by performing an understanding of food hygiene and beverages to be consumed each day also involves aspects of knowledge and behavior which less supportive of a healthy lifestyle. Time series analysis and projections on morbidity can give information related to the morbidity that occurs. In RSUD Dr. Soetomo hospital, the number of patients per month on average to 200 patients. With the high number of GEs patients, then time series analysis will be done to GEs patients in the medical records of inpatient unit of RSUD Dr. Soetomo hospital based on monthly data in 2011 to 2014, viewed by the occurrences of this problem each month. The predicted results of GEs patients number which are hospitalized in May 2014 increased in the number of patients to 95 patients; In June-August decline in the number of patients to 80, 59, and 16 patients; September-November increased to 62, 103, and 142 patients; May to November 2014 has increased the number of male patients in May as many as 54 patients; June-August 
2014 decreased the number of patients to 48, 38, and 10 patients; September-November 2014 increased the number of patients as much as 29, 65, and 83 patients in RSUD Dr. Soetomo hospital.

Keywords: Time Series Analysis, Gastroenteritis (GE), Medical Record

\section{PENDAHULUAN}

Manusia dapat diartikan sebagai sistem terbuka yang merespon terhadap stimulus atau rangsangan baik yang bersumber dari lingkungan internal maupun eksternal. Proses interaksi ini dikenal sebagai adaptasi untuk memelihara kemampuan daya tahan tubuh. Manusia memiliki kemampuan beradaptasi baik secara biologis maupun psikologis. Tujuan adaptasi biologis adalah mempertahankan kelangsungan hidup atau proses internal atau proses eksternal agar tetap stabil. Tubuh memiliki umpan balik fisiologi dan mekanisme kompensasi yang akan membantu proses di dalam tubuh berlangsung dengan baik sehingga tercapai fungsi yang optimal. Jika kemampuan untuk mempertahankan keseimbangan hilang, maka akan terjadi perubahanperubahan organ tubuh.

Masalah Gastroenteritis (GE) ialah masalah kesehatan masyarakat yang penanggulangannya tidak hanya dilakukan dengan pendekatan medis dan pelayanan kesehatan saja, melainkan dengan melakukan pemahaman tentang kebersihan makanan dan minuman yang akan dikonsumsi setiap harinya juga menyangkut aspek pengetahuan dan perilaku yang kurang mendukung pola hidup sehat. $G E$ ialah infeksi saluran pencernaan yang disebabkan oleh berbagai enterogen termasuk bakteri, virus, dan parasit, tidak toleran terhadap makanan tertentu atau mencerna toksin yang ditandai dengan muntah-muntah dan diare yang berakibat kehilangan cairan dan elektrolit yang menimbulkan dehidrasi dan gangguan keseimbangan elektrolit.

Dari observasi awal yang telah dilakukan pada tangal 12 - 16 Maret 2014 khususnya pada bagian Unit Rekam Medis Rawat Inap Rumah Sakit Umum Daerah
(RSUD) Dr. Soetomo Surabaya dengan melihat data pelaporan bulanan, saat ini jumlah kasus penyakit $G E$ dengan kode ICD A09 setiap bulannya selalu berada di urutan pertama dalam daftar 10 penyakit terbanyak pasien rawat inap.

Menurut Pedoman Pengelolaan Rekam Medis Rumah Sakit Di Indonesia, Departemen Kesehatan Republik Indonesia (1997:7), salah satu faktor yang menentukan dalam upaya pelayanan kesehatan ialah tertib administrasi. Untuk tercapainya tertib administrasi dalam rangka upaya peningkatan pelayanan kesehatan adalah pengadaan kegiatan rekam medis.

Untuk meningkatkan mutu pelayanan di rumah sakit sangat diperlukan adanya penyelenggaraan rekam medis yang merupakan salah satu faktor untuk menentukan baik dan buruknya pelayanan administrasi yang diberikan.Tanpa dukungan sistem rekam medis yang baik dan benar, pelayanan kesehatan/rumah sakit kurang berhasil dalam meningkatan mutu pelayanannya sebagaimana yang diharapkan.Untuk menjalankan tugas tersebut perlu didukung adanya unit-unit pembantu yang mempunyai tugas spesifik, di antaranya ialah unit rekam medis.Unit rekam medis mempunyai tanggungjawab terhadap pengelolahan data pasien menjadi informasi kesehatan yang berguna bagi pengambilan keputusan (Savitri, 2011).

Menurut Keputusan Menkes No.377/Menkes/SK/III/2007, Rekam medis mempunyai 7 kompetensi yang harus dimiliki oleh seorang perekam medis yaitu meliputi :

1. Klasifikasi dan kodifikasi penyakit, masalah-masalah yang berkaitan dengan kesehatan dan tindakan medis

2. Aspek hukum dan etika profesi 
3. Manajemen rekam medis dan informatika kesehatan

4. Menjaga mutu rekam medis

5. Statistika kesehatan

6. Manajemen unit kerja rekam medis dan informatika kesehatan

7. Kemitran profesi

Dari 7 kompetensi di atas peneliti memfokuskan penelitian pada kompetensi ke-5 tentang kemampuan statistika kesehatan : "Perekam Medis mampu menggunakan statistika kesehatan untuk menghasilkan informasi dan perkiraan yang bermutu tinggi sebagai dasar perencanaan dan pengambilan keputusan di bidang pelayanan kesehatan" Kemampuan tersebut guna memberikan informasi kesehatan terhadap masyarakat luas juga mampu melakukan analisis data penyakit, laporan morbiditas dan mortalitas dalam penyajian data berbentuk lisan dan tulisan.

Analisis time series dan proyeksi tentang morbiditas bisa memberikan informasi yang berkaitan dengan angka kesakitan yang terjadi. Sesuai dengan kegunaan rekam medis melakukan analisis time series dan proyeksi morbiditas pada penelitian ini dimanfaatkan data sekunder berkas rekam medis jumlah penderita $G E$ rawat inap di RSUD Dr. Soetomo Surabaya, dimana data berkas rekam medis tersebut telah diolah sendiri oleh pihak rumah sakit.

Dalam melakukan analisis time series, perekam medis sangat berperan dalam pengolahan data agar menghasilkan informasi maupun interpretasi dalam suatu perhitungan. Selain itu juga dapat memudahkan petugas rekam medis atau petugas rumah sakit lainnya dalam melihat jumlah kasus suatu penyakit dan melakukan suatu kegiatan peramalan jumlah kasus suatu penyakit dimasa yang akan datang khususnya penyakit $G E$.

RSUD Dr. Soetomo Surabaya merupakan rumah sakit pemerintah dengan status tipe A Pendidikan milik Pemerintah Provinsi Jawa Timur. Yang merupakan rumah sakit rujukan terbesar di Indonesia
Timur serta memiliki sarana pelayanan kesehatan berupa layanan rawat inap, rawat jalan, dan rawat darurat.

Di RSUD Dr. Soetomo Surabaya jumlah penderita GE perbulan rata-rata mencapai 200 pasien. Dengan tingginya jumlah pasien GE tersebut, maka akan dilakukan analisis time series pada penderita GE di bagian unit rekam medis rawat inap RSUD Dr. Soetomo Surabaya berdasarkan data bulanan tahun 2011 sampai 2014, dilihat dari kejadian setiap bulannya. Untuk analisis time series sendiri belum pernah dilakukan di RSUD Dr. Soetomo Surabaya, khususnya pada penderita GE di unit rekam medis rawat inap.

\section{Rumusan Masalah}

Berdasarkan latar belakang di atas, rumusan masalah yang diajukan pada penelitian ini ialah "Bagaimana memprediksi jumlah penderita $G E$ rawat inap dengan analisis time series metode Winter berdasarkan data bulanan di SeksiRekam Medis RSUD Dr. Soetomo Surabaya?"

\section{Tujuan}

Memprediksi jumlah penderita $G E$ rawat inap pada tiga bulan berikutnya berdasarkan data bulanan di SeksiRekam Medis dari Tahun 2011 sampai Tahun 2014 di Rawat Inap RSUD Dr. Soetomo Surabaya dengan menggunakan Analisis Time Series Metode Winter.

\section{Kajian Pustaka}

Menurut Pedoman Pengelolaan Rekam Medis Rumah Sakit Di Indonesia, Departemen Kesehatan Republik Indonesia (1997:6), rekam medis ialah keterangan baik yang tertulis maupun terekam tentang identitas, anamnesis, penentuan fisik laboratorium, diagnosis segala pelayanan dan tindakan medis yang diberikan pada pasien, dan pengobatan baik yang dirawat inap, rawat jalan, maupun yang mendapat pelayanan gawat darurat. 
Menurut PerMenKes RI No.269/MenKes/Per/III/2008. Kegunaan berkas rekam medis yaitu, sebagai berikut.

a. Dasar pemeliharaan kesehatan dan pengobatan pasien.

b. Bahan pembuktian dalam perkara hukum.

c. Bahan untuk keperluan penelitian dan pendidikan.

d. Dasar pembayaran biaya pelayanan kesehatan

e. Bahan untuk menyiapkan statistika kesehatan

Semua bentuk catatan, baik hasil rekapitulasi harian, maupun lembaranlembaran formulir rekam medis merupakan bahan yang perlu diolah. Untuk selanjutnya dipakai sebagai bahan laporan rumah sakit. Sebelum dilakukan pengolahan, berkas-berkas rekam medis tersebut diteliti kelengkapannya baik isi maupun jumlahnya. Rekapitulasi dari sensus harian diolah untuk menyiapkan laporan yang menyangkut kegiatan rumah sakit. Formulir-formulir rekam medis diolah untuk menyiapkan laporan yang menyangkut morbiditas dan mortalitas (DepKes RI, 1993:18).

\section{Analisis}

Menurut Patton 1980 (dalam 2000:103) menjelaskan bahwa:

Menurut Bogdan (dalam Sugiyono 2008:244) analisis adalah proses mencari dan menyusun secara sistemis data yang diperoleh dari hasil wawancara, catatan lapangan, dan bahan-bahan lain, sehingga dapat mudah dipahami, dan temuannya dapat diinformasikan kepada orang lain. Analisis data dilakukan dengan mengorganisasikan data, menjabarkan ke dalam unit-unit, melakukan sintesis, menyusun ke dalam pola, memilih mana yang penting dan yang akan dipelajari, dan membuat kesimpulan yang dapat diceritakan kepada orang lain.

\section{Analisis Time Series (deret waktu)}

Perkembangan penderita $G E$ tidak mungkin diperhitungkan dan diramalkan berdasarkan renungan semata. Hanya dengan pengamatan yang berulang-ulang perkembangan penderita $G E$ dapat diperhitungkan dan diramalkan dengan tepat dan teliti. Peramalan juga merupakan alat yang penting dalam pengambilan keputusan yang bersifat strategis dan taktis bagi rumah sakit.

Ada 2 hal pokok yang harus diperhatikan dalam proses pembuatan peramalan yang akurat dan bermanfaat. Pertama ialah pengumpulan data yang relevan berupa informasi yang dapat menghasilkan peramalan yang akurat. Kedua ialah pemilihan teknik peramalan yang tepat yang akan memanfaatkan informasi data yang diperoleh seoptimal mungkin (Lincolin Arsyad, 2009:35).

Menurut Lincolin Arsyad (2009:37), setiap variabel yang terdiri dari data yang dikumpulkan, dicatat atau diobservasi sepanjang waktu yang berurutan disebut data runtut waktu (time series). Analisis runtut waktu dilakukan untuk menemukan pola pertumbuhan atau perubahan masa lalu, yang dapat digunakan untuk memperkirakan pola pada masa yang akan datang. Analisis ini cukup penting dalam proses peramalan dan membantu mengurangi kesalahan dalam peramalan tersebut. Dalam analisis runtut waktu terdapat 4 komponen yaitu:

\section{a. Trend}

Trend ialah perkembangan jangka panjang dalam suatu runtut waktu yang dapat digambarkan dengan sebuah garis lurus atau sebuah kurva kekuatan-kekuatan dasar yang menghasilkan atau mempengaruhi trend dari suatu seri adalah perubahan populasi, perubahan harga, perubahan teknologi, dan peningkatan produktivitas. Dalam analisis trend variabel bebasnya adalah waktu. Seorang peneliti harus memetakan data dalam bentuk aritmatika dan semilogaritma sebelum memilih persamaan trend berdasarkan bentuk umum dari grafik yang tampak. Jika grafik berbentuk garis lurus dalam skala aritmatika, maka peneliti akan menggunakan persamaan linier dalam analisis datanya. Jika data dinyatakan dalam bentuk semilogaritma dan terbentuk 
grafik dengan garis lurus, maka peneliti akan memilih model eksponensial dalam datanya. Metode untuk menjelaskan trend linier ialah metode kuadrat terkecil.

b. Variasi Siklis

Komponen siklis ialah suatu seri fluktuasi seperti gelombang atau siklus yang mempengaruhi keadaan ekonomi selama lebih dari satu tahun. Hal tersebut dapat dilihat dari perbedaan antara nilai yang diharapkan (trend) dengan nilai yang sebenarnya yaitu variasi residual yang berfluktusi sekitar trend. Komponen siklis dan tak beraturan dari data runtut waktu dapat diidentifikasi dengan cara menghilangkan pengaruh trend, metode ini disebut metode residual (residual method). Tahap metode residual tergantung pada dimulainya menganalisis dengan data tahunan, bulanan, atau kuartalan. Jika data yang digunakan ialah data bulanan atau kuartalan, maka pengaruh trend dan komponen-komponen musiman harus dihilangkan. Jika datanya ialah data tahunan, maka pengaruh trend yang dihilangkan.

c. Musiman

Fluktuasi musiman biasanya dijumpai pada data yang dikelompokan secara kuartalan, bulanan, atau mingguan. Variasi musiman ini menggambarkan pola perubahan yang berulang secara teratur dari waktu ke waktu. Komponen musiman runtut waktu diukur dalam bentuk angka indeks. Interpretasi angka indeks ini, yang mencerminkan besarnya pengaruh musiman untuk suatu segmen tahun tertentu, berkaitan dengan perbandingan nilai terhitung atau nilai yang diharapkan dari segmen tersebut (bulan, kuartal, dan sebagainya).

d. Fluktuasi tak beraturan

Komponen tidak beraturan terbentuk dari fluktuasi-fluktuasi yang disebabkan oleh peristiwa-peristiwa yang tidak terduga seperti perubahan cuaca, pemogokan, perang, pemilihan umum, rumor perang, dan lain-lain.

\section{Metode Pemulusan Eksponensial (Lincolin Arsyad, 1994)}

Pemulusan eksponensial (exponential smoothing) ialah suatu prosedur yang mengulang perhitungan secara terusmenerus dengan menggunakan data terbaru. Metode ini berdasarkan pada perhitungan rata-rata (pemulusan) data masa lalu secara eksponensial. Setiap data diberi bobot, dimana data yang lebih baru diberi bobot yang lebih besar. Bobot yang digunakan ialah $\alpha$ untuk data yang paling baru, $\alpha(1-\alpha)$ digunakan untuk data yang agak lama, $\alpha(1-\alpha)^{2}$ untuk data yang lebih lama lagi, dan seterusnya.

Dalam bentuk yang mulus, ramalan yang baru (untuk waktu $t+1$ ) dapat dianggap sebagai rata-rata yang diberi bobot terhadap data terbaru (pada waktu $t$ ) dan ramalan yang lama (untuk waktu $t$ ). bobot $\alpha$ diberikan pada data terbaru, dan bobot $1-\alpha$ diberikan pada ramalan yang lama, dimana $0<\alpha<1$. Dengan demikian:

Ramalan baru $=\alpha \times$ (data baru $)+(1$ - $\alpha$ ) x (ramalan yang lama)

Secara matematis, persamaan pemulusan eksponensial dapat ditulis:

$$
\hat{\mathrm{Y}}_{\mathrm{t}+1}=\alpha \mathrm{Y}_{\mathrm{t}}+(1-\alpha) \hat{\mathrm{Y}}_{\mathrm{t}}
$$

Di mana:

$\hat{\mathrm{Y}}_{\mathrm{t}+1}=$ nilai ramalan untuk periode berikutnya

$\alpha=$ konstanta pemulusan $(0<\alpha<$ 1)

$\mathrm{Y}_{\mathrm{t}}=$ data baru atau nilai $\mathrm{Y}$ yang sebenarnya pada periode $t$

$\hat{\mathrm{Y}}_{\mathrm{t}}=$ nilai pemulusan yang lama atau rata-rata yang dimuluskan hingga periode $t-1$

Agar $\alpha$ dapat diinterpretasikan dengan lebih baik, persamaan pemulusan eksponensial tersebut diuraikan sebagai berikut:

$$
\begin{aligned}
\hat{\mathrm{Y}}_{\mathrm{t}+1} & =\alpha \mathrm{Y}_{\mathrm{t}}+(1-\alpha) \hat{\mathrm{Y}}_{\mathrm{t}} \\
& =\alpha \hat{Y}_{\mathrm{t}}+\hat{\mathrm{Y}}_{\mathrm{t}}-\alpha \hat{\mathrm{Y}}_{\mathrm{t}} \\
& =\hat{\mathrm{Y}}_{\mathrm{t}+} \alpha\left(\mathrm{Y}_{\mathrm{t}}-\hat{\mathrm{Y}}_{\mathrm{t}}\right)
\end{aligned}
$$

Secara sederhana pemulusan eksponensial ialah nilai ramalan lama $\left(\hat{\mathrm{Y}}_{\mathrm{t}}\right)$ ditambah $\alpha$ (alpha) dikalikan dengan 
tingkat kesalahan $\left(\mathrm{Y}_{\mathrm{t}^{-}} \hat{\mathrm{Y}}_{\mathrm{t}}\right)$ dari ramalan yang lama.

Konstanta pemulusan $\alpha$ berfungsi sebagai faktor penimbang. Jika $\alpha$ mendekati 1 , berarti nilai ramalan yang baru sudah memasukkan faktor penyesuaian untuk setiap tingkat kesalahan yang terjadi pada nilai ramalan yang lama. Sebaliknya, bila $\alpha$ mendekati 0 , berarti nilai ramalan yang baru hampir sama dengan nilai ramalan yang lama. Besaran bobot yang dilambangkan dengan $\alpha$ merupakan kunci dari analisis. Diperlukan nilai $\alpha$ yang kecil, jika menginginkan hasil ramalan yang stabil dan variasi random dimuluskan. Dan sebaliknya diperlukan nilai $\alpha$ yang besar, jika menginginkan respon yang cepat terhadap perubahanperubahan pola observasi. Metode untuk mengestimasi $\alpha$ ialah denngan menggunakan prosedur interatif yang meminimumkan mean square error (MSE). Pada umumnya peramalan dilakukan dengan $\alpha$ yang sama dengan 0,1 , $0,2,0,3, \ldots .0,9$. Nilai $\alpha$ yang menghasilkan tingkat kesalahan yang paling kecil ialah yang dipilih dalam peramalan.

a. Pemulusan Eksponensial untuk Variasi Trend dan Musiman

Metode ini merupakan metode yang digunakan untuk dalam pemulusan trend dan musiman. Untuk meminimumkan MSE, maka teknik Winter yang umumnya baik untuk digunakan, dengan pemakaian program komputer yang secara otomatis memilih konstanta pemulusan yang paling baik, akan semakin mengurangi besarnya MSE. Pemulusan eksponensial merupakan teknik yang sudah umum dipakai untuk peramalan jangka pendek. Keuntungan utamanya ialah biaya yang rendah dan kemudahan pemakaiannya.

Dasar peramalan dalam rata-rata bergerak sederhana dan pemulusan eksponensial ialah rata-rata tertimbang pengukuran-pengukuran masa lalu. Dasar pertimbangannya ialah bahwa rata-rata masa lalu mengandung informasi mengenai apa yang akan terjadi di masa yang akan datang. Karena masa lalu mengandung fluktuasi random dan informasi mengenai pola variabel, maka diperlukan usaha untuk memuluskan datadata tersebut. Pendekatan ini mengasumsikan bahwa fluktuasi-fluktuasi ekstrem menyatakan tingkat pengaruh random dalam rangkaian data.

Rata-rata bergerak berkaitan dengan penghitungan nilai tengah sejumlah nilai suatu variabel. Rata-rata ini menjadi random untuk periode berikutnya, kemudian proses ini diulang-ulang sampai diperoleh ramalan untuk periode yang dikehendaki.

\section{Gastroenteritis (GE)}

\section{Pengertian}

$G E$ atau diare akut adalah kekerapan dan keenceran BAB dimana frekuensinya lebih dari 3 kali perhari dan banyaknya lebih dari 200 - 250 gram (Syaiful Noer, 1996 ). Istilah $G E$ digunakan secara luas untuk menguraikan pasien yang mengalami perkembangan diare dan atau muntah akut. Istilah ini menjadi acuan bahwa terjadi proses inflamasi dalam lambung dan usus.

\section{Menurut Keputusan Menkes RI No.1216/Menkes/SK/XI/2001 tentang pedoman pemberantasan penyakit diare dinyatakan bahwa penyakit diare masih merupakan masalah kesehatan masyarakat Indonesia, baik ditinjau dari angka kesakitan dan angka kematian serta} Kejadian Luar Biasa (KLB) yang ditimbulkan. Penyebab utama kematian pada penyakit diare adalah dehidrasi sebagai akibat kehilangan cairan dan elektrolitnya melalui tinjanya. Di negara berkembang prevalensi yang tinggi dari penyakit diare merupakan kombinasi dari sumber air yang tercemar, kekurangan protein dan kalori yang menyebabkan turunnya daya tahan tubuh.

\section{Faktor infeksi}

Infeksi internal yaitu saluran pencernaan yang merupakan penyebab utama diare.Pada saat ini telah dapat diidentifikasi tidak kurang dari 25 jenis 
mikroorganisme yang dapat menyebabkan diare pada anak

dan bayi.Penyebab itu dapat digolongkan lagi kedalam penyakit yang ditimbulkan adanya virus, bakteri, dan parasit usus.Penyebab utama oleh virus yang terutama ialah rotavirus $(40-60 \%)$ sedangkan virus lainnya ialah virus Norwalk, Astrovirus, Calcivirus, Coronavirus, Minirotavirus dan virus bulat kecil. Bakteri-bakteri yang dapat menyebabkan penyakit itu adalah Aeromonas hidrophilia, Bacillus cereus, Campylobacter jejuni, Clostridium defficile, Clostridium perfringens, E. Coli, Plesiomonas, Shigelloides, Salmonella spp, Staphylococcus aureus, Vibrio cholerae, dan Yersinia enterocolitica, sedangkan penyebab $G E$ (diare akut) oleh parasit adalah Balantidium coli, Capillaria philippinensis, cryptosporidium, Entamoeba histolitica, Giarsia lamblia, Isospora billi, Fasiolopsis buski, Sarcocystis suihominis, Strongiloides stercoralis, dan Trichuris trichuria.

3. Gejala Klinik

Pasien dengan diare akibat infeksi sering mengalami nausea, muntah, nyeri perut sampai kejang perut, demam dan diare terjadi renjatan hipovolemik harus dihindari kekurangan cairan menyebabkan pasien akan merasa haus, lidah kering, tulang pipi menonjol, turgor kulit menurun, serta suara menjadi serak, gangguan biokimiawi seperti asidosis metabolik akan menyebabkan frekuensi pernafasan lebih cepat dan dalam (pernafasan kusmaul). Bila terjadi renjatan hipovolemik berat maka denyut nadi cepat (lebih dari $120 \mathrm{kali} / \mathrm{menit}$ ) tekanan darah menurun tak terukur, pasien gelisah, muka pucat, ujung ekstremitas dingin dan kadang sianosis, kekurangan kalium dapat menimbulkan aritmia jantung. Perfusi ginjal dapat menurun sehingga timbul anuria, sehingga bila kekurangan cairan tak segera diatasi dapat timbul penulit berupa nekrosis tubular akut.Secara klinis dianggap diare karena infeksi akut dibagi menjadi dua golongan pertama, kolerifrom, dengan diare yang terutama terdiri atas cairan saja.Kedua disentriform, pada saat diare didapatkan lendir kental dan kadang-kadangdarah.

\section{Metode Penelitian \\ Jenis Penelitian}

Berdasarkan tujuan penelitian ini, maka peneliti menggunakan metode analisis kuantitatif dengan menggunakan teknik statistik yang digunakan untuk menganalisis data sampel dan hasilnya diberlakukan untuk populasi khususnya pada penderita $G E$ secara obyektif. Berdasarkan manfaat dan kegunaan penelitian ini termasuk dalam studi evaluatif dengan pendekatan retrospektif yaitu dengan melihat laporan statistik bulan sebelumnya (Notoatmodjo, 2005:27).

\section{Tempat dan Waktu Penelitian}

Penelitian ini dilakukan pada bulan Mei 2014, dan bertempat di Seksi Rekam Medis RSUD Dr. Soetomo Surabaya.

\section{Populasi dan Sampel}

a). Populasi

Populasi merupakan keseluruhan subyek penelitian yang akan diteliti (Arikunto, 2002:108). Peneliti menyimpulkan bahwa populasi dalam penelitian ini ialah seluruh data bulanan jumlah penderita $G E$ rawat inap di RSUD Dr. Soetomo Surabaya Tahun 2011-2014.

b). Sampel

Menurut Notoatmodjo (2002:92) sampel merupakan sebagian dari keseluruhan obyek yang akan diteliti dan dianggap mewakili seluruh populasi. Maka sampel yang diambil oleh peneliti ialah data sekunder jumlah penderita $G E$ rawat inap di RSUD Dr. Soetomo Surabaya perbulan dari tahun 2011 hingga 2014.

\section{Variabel Penelitian dan Definisi Operasional Variabel}

a. Variabel Penelitian

Variabel penelitian ialah sesuatu yang digunakan sebagai ciri, sifat atau ukuran yang dimiliki dan didapatkan 
oleh satuan penelitian tentang sesuatu konsep pengertian tertentu (Notoatmodjo, 2002:70). Pada penelitian ini variabel yang akan diteliti ialah jumlah penderita $G E$ rawat inap perbulan menurut jenis kelamin dan jumlah total penderita $G E$ perbulan.

b. Definisi Operasional Variabel

Jumlah penderita $G E$ rawat inap perbulan menurut jenis kelamin yaitu jumlah penderita $G E$ pada tiap bulannya berdasarkan jenis kelamin. Jumlah total penderita $G E$ rawat inap perbulan ialah total seluruh penderita $G E$ rawat inap tiap bulan.

\section{Teknik Pengumpulan Data}

Pengumpulan data dengan metode dokumentasi tentang data sekunder mengenai hal-hal atau variabel penderita $G E$. Pada penelitian ini yang diangkat menjadi sumber data ialah dengan menggunakan data pasien penderita $G E$ rawat inap di RSUD Dr. Soetomo Surabaya dengan menggunakan Laporan Bulanan Penderita GE Tahun 2011-2014.

\section{Teknik Analisis Data}

Teknik analisis data dengan analisis deskriptif dalam bentuk tabel dan diagram. Analisis lebih lanjut menggunakan Pemulusan Eksponensial untuk Variasi Trend dan Musiman untuk melihat pola kejadian dan memprediksi jumlah penderita $G E$ rawat inap pada bulan berikutnya. Metode ini merupakan metode yang digunakan dalam pemulusan trend dan musiman. Terdapat empat persamaan yang digunakan dalam model Winter ialah sebagai berikut:

1. Pemulusan Eksponensial

$$
A_{t}=\alpha \stackrel{Y_{t}}{+}+(1-\alpha)\left(A_{t-1}+T_{t-1}\right)
$$

2. Estimasi Trend

$$
T_{t}=\gamma\left(A_{t}-A_{t-1}\right)+(1-\gamma) T_{t-1}
$$

3. Estimasi Musiman

$$
Y_{t}
$$

$$
\mathrm{S}_{\mathrm{t}}=\delta \quad+(1-\delta) \mathrm{S}_{\mathrm{t}-\mathrm{t}}
$$

4. Ramalan pada periode $p$ di masa datang

$$
\hat{\mathrm{Y}}_{\mathrm{t}+\mathrm{p}}=\left(\mathrm{A}_{\mathrm{t}}+\mathrm{p} \mathrm{T}_{\mathrm{t}}\right) \mathrm{S}_{\mathrm{t}-\mathrm{L}+\mathrm{p}}
$$

$\mathrm{A}_{\mathrm{t}}=$ nilai pemulusan yang baru

$\alpha=$ konstanta pemulusan untuk data $(0 \leq$ $\alpha \leq 1)$

$\mathrm{Y}_{\mathrm{t}}=$ data yang baru atau yang sebenarnya pada periode $t$

$\gamma=$ konstanta pemulusan untuk estimasi trend $(0 \leq \gamma \leq 1)$

1. = konstanta pemulusan untuk estimasi musiman $(0 \leq \delta \leq 1)$

$\mathrm{T}_{\mathrm{t}}=$ estimasi trend

$\mathrm{S}_{\mathrm{t}}=$ estimasi musiman

$\mathrm{p}=$ periode yang diramalkan

$\mathrm{L}=$ panjangnya musim

$\hat{\mathrm{Y}}_{\mathrm{t}+\mathrm{p}}=$ ramalan pada periode $\mathrm{p}$

(Lincolin Arsyad, 2009)

\section{Hasil Penelitian Dan Pembahasan}

Di RSUD Dr. Soetomo kasus $G E$ mengalami peningkatan jumlah penderita di bulan-bulan tertentu dari tahun 20112014. Pada awal tahun 2011 penderita $G E$ sebanyak 106, kemudian mengalami peningkatan pada 4 bulan berikutnya sebanyak 126 dan menurun secara terus menerus sampai bulan ke 8 menjadi sebanyak 46 penderita dan kemudian mengalami peningkatan hingga akhir tahun menjadi 118 penderita. Tahun 2012 jumlah penderita $G E$ terbanyak terjadi pada bulan oktober dan jumlah paling sedikit terjadi pada bulan agustus. Demikian pula pada tahun 2013 jumlah penderita $G E$ terbanyak terjadi pada bulan januari dan yang terendah jumlahnya terjadi pada bulan juli. Tahun 2014 hinga bulan april, jumlah penderita terbanyak terjadi pada bulan januari dan terendah pada bulan februari.

Dari jumlah berdasarkan jenis kelamin, laki-laki lebih banyak jumlahnya dibandingkan perempuan. Dari tahun 2011 hingga april 2014 jenis kelamin laki-laki lebih mendominasi dengan selisih 269 dari jumlah penderita perempuan. 
Kejadian tinggi dan rendahnya jumlah penderita $G E$ juka dilihat dari data-data tahun 2011-2014 dipengaruhi oleh adanya faktor musiman, karena tingginya jumlah penderita terjadi pada bulan-bulan tertentu dan kemudian turun di bulan-bulan tertentu berikutnya.

Turunnya jumlah penderita bisa terjadi karena adanya program penyuluhan ksehatan pemerintah melalui rumah sakit maupun puskesmas tentang penyakit $G E$, memberikan penyukuhan tentang kebersihan lingkungan, kebersihan makanan dan minuman yang dikonsumsi setiap harinya.

\section{Kasus Gastroenteritis}

Diawal tahun 2014 kasus $G E$ mengalami peningkatan jumla penderita dari bulan ke bulan seiring bergantinya musim kemarau ke musim hujan. Jumlah kasus $G E$ di RSUD Dr. Soetomo menigkat dari 61 pasien pada April 2013 menjadi 95 pasien pada April 2014, sehingga jumlah penderita diare mengalami peningkatan persen. Dari hasil pengamatan, kasus $G E$ selalu berada pada urutan pertama dalam daftar 10 penyakit terbanayak di RSUD Dr. Soetomo untuk bulan Januari hingga Maret 2014. Peningkatan jumlah penderita tersebut lebih sering terjadi karena datangnya usim penghujan menjadi penyebab mewabahnya berbagai penyakit, sebagai akibat kurangnya kebersihan makanan dan lingkungan. Salah satunya adalah merebaknya penyakit diare (Gastroenteritis) dan muntaber.

Dalam upaya mengurangi banyaknya jumlah penderita $G E$ di Surabaya, diadakan penyuluhan tentang kebersihan makanan, kebersihan individu, sanitasi lingkungan dan air yang baik, serta vaksinasi. Kebersihan individu bisa dimulai dengan mencuci tangan sebelum makan dan memasak makanan sampai matang.

\section{Analisis Time Series}

Tujuan penelitian yang telah dikemukakan pada bab 1 sebelumnya yaitu untuk mengetahui pola jumlah dan memprediksi jumlah penderita $G E$ rawat inap pada bulan berikutnya di RSUD Dr. Soetomo yang menggunkan metode analisis kantitatif dengan menggunakan statistik inferensial untuk meneliti data sekunder dari penderita $G E$ rawat inap RSUD Dr. Soetomo, dimana data tersebut digunakan untuk memprediksi jumlah penderita $G E$ bebeapa bulan berikutnya, juga untuk acuan pihak manajemen dalam melakukan upaya perencanaan terhadap kasus GE di RSUD Dr. Soetomo. Penelitian ini enggunakan pendekatan retrospektif yaitu dengan melihat laporan statistik bulan sebelumnya, untuk mengevaluasi dan menerapkan jumlah tersebut ke dalam model Winter method.

Dengan mencoba memasukkan angka konstanta pemulusan yang berkisar antara $0 \leq 1$ untuk $\alpha, \gamma$, dan $\delta$ tersebut mempengaruhi angka kesalahan dalam peramalan yang akan dilakukan. Dalam perhitungan untuk memproyeksi jumlah penderita pada bulan berikutnya, peneliti menggunakan konstanta pemulusan $\alpha=$ $0,9, \gamma=0,3, \delta=0,9$ untuk memperkecil angka kesalahan dalam peramalan.

Lokasi penelitian ini adalah bagian unit rekam medis rawat Inap RSUD Dr. Soetomo. Data diambil dari seluruh jumlah penderita $G E$ rawat inap di RSUD Dr. Soetomo dari bulan Januari 2011 - April 2014. Berdasarkan penelitian hasil data mengenai data penderita $G E$ rawat inap RSUD Dr. Soetomo diperoleh data sebagai berikut :

Analisis datatime series jumlah penderita $G E$ rawat inap berdasarkan jenis kelamin

Tabel 4.1 Jumlah Penderita $G E$ Rawat Inap RSUD Dr. SoetomoBerdasarkan Jenis KelaminJanuari Tahun 2011 - April 2014

\begin{tabular}{crrrrrrrr}
\hline Bulan & \multicolumn{2}{c}{2011} & \multicolumn{2}{c}{2012} & 2013 & \multicolumn{2}{c}{2014} \\
\cline { 2 - 8 } & $\mathrm{L}$ & $\mathrm{P}$ & $\mathrm{L}$ & $\mathrm{P}$ & $\mathrm{L}$ & $\mathrm{P}$ & $\mathrm{L}$ & $\mathrm{P}$ \\
Januari & 53 & 53 & 51 & 42 & 73 & 67 & 39 & 38 \\
\hline
\end{tabular}




\begin{tabular}{lrrrrrrrr}
\hline \multicolumn{1}{c}{ Bulan } & \multicolumn{1}{c}{2011} & \multicolumn{2}{c}{2012} & \multicolumn{3}{c}{2013} & \multicolumn{2}{c}{2014} \\
\cline { 2 - 9 } & L & P & L & P & L & P & L & P \\
Februari & 51 & 56 & 59 & 57 & 59 & 57 & 33 & 27 \\
Maret & 52 & 53 & 56 & 50 & 62 & 37 & 30 & 35 \\
April & 42 & 44 & 22 & 18 & 31 & 30 & 42 & 27 \\
Mei & 70 & 56 & 68 & 58 & 54 & 53 & & \\
Juni & 50 & 47 & 76 & 64 & 40 & 50 & & \\
Juli & 44 & 48 & 64 & 32 & 41 & 31 & & \\
Agustus & 22 & 24 & 26 & 26 & 47 & 34 & & \\
Septembe & 31 & 29 & 37 & 39 & 68 & 47 & \\
r & & & & & & & \\
Oktober & 68 & 64 & 79 & 66 & 73 & 60 & & \\
Novembe & 67 & 65 & 78 & 58 & 73 & 57 & & \\
r & & & & & & & \\
Desember & 55 & 63 & 57 & 57 & 44 & 28 & & \\
Total & 1207 & 1240 & 1216 & 271 \\
\hline \hline
\end{tabular}

Sumber : Data Unit Rekam Medis Rawat Inap Tahun 2011-2014

Data yang diperoleh pada waktu penelitian adalah 3 tahun mulai tahun 2011-2014. Jumlah penderita $G E$ rawat inap RSUD Dr. Soetomo banyak terjadi pada jenis kelamin laki-laki dengan jumlah 2087 penderita, sedangkan jenis kelamin perempuan dengan jumlah 1847 penderita. Pada masing-masing bulan di tiap tahunnya jumlah penderita $G E$ mengalami perubahan jumlah secara tidak teratur, maka dalam perhitungan untuk memproyeksi jumlah penderita $G E$ pada bulan berikutnya peneliti menggunakan analisis time series dalam model Winter method.

Untuk perhitungan dalam memprediksi jumlah penderita $G E$ rawat inap berdasarkan jenis kelamin, peneliti menghitung dari masing-masing jenis kelamin yaitu laki-laki dan perempuan.

Penderita $G E$ laki-laki

Distribusi penderita GEdi Instalasi Rawat Inap RSUD Dr. Soetomo Surabaya berdasarkan Jenis Kelamin Laki-laki pada bulan Januari 2011 - April 2014 tampak pada tabel dibawah ini:
Tabel 4.2 Jumlah Penderita GE Rawat Inap RSUD Dr. SoetomoBerdasarkan Jenis Kelamin Laki-laki Januari 2011 - April 2014

\begin{tabular}{lcccc}
\hline \hline \multicolumn{1}{c}{ Bulan } & 2011 & 2012 & 2013 & 2014 \\
\hline Januari & 53 & 51 & 73 & 39 \\
Februari & 51 & 59 & 59 & 33 \\
Maret & 52 & 56 & 62 & 30 \\
April & 42 & 22 & 31 & 42 \\
Mei & 70 & 68 & 54 & \\
Juni & 50 & 76 & 40 & \\
Juli & 44 & 64 & 41 & \\
Agustus & 22 & 26 & 47 & \\
September & 31 & 37 & 68 & \\
Oktober & 68 & 79 & 73 & \\
November & 67 & 78 & 73 & \\
Desember & 55 & 57 & 44 & \\
Total & 605 & 673 & 665 & 144 \\
\hline \hline
\end{tabular}

Sumber : Data Unit Rekam Medis Rawat Ina p Tahun 2011 - 2014

Untuk mengetahui analisa pola data pasien berjenis kelamin laki-laki menggunakan autocorrelation function, diketahui bahwa ada unsur musiman. Hal ini tampak pada adanya garis kebawah dan pada titik berikutnya kebawah lagi.

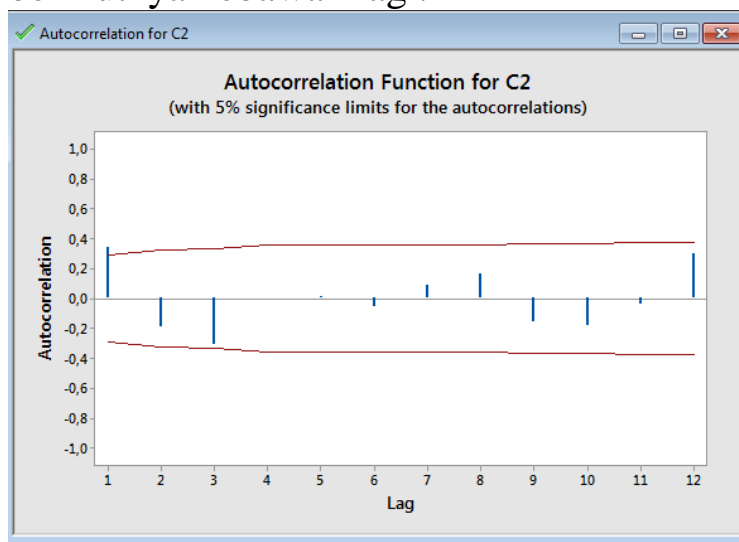

Grafik 4.2 Hasil autocorrelation function untuk Data Penderita GE Rawat Inap RSUD Dr. SoetomoBerdasarkan Jenis Kelamin Laki-lakiJanuari 2011 - April 2014

Dari gambar 4.2 dan tabel 4.2 di atas dapat dilihat secara rinci jumlah penderita $G E$ pada tiap bulannya berubah secara tidak teratur, maka perhitungan untuk 
memproyeksi jumlah penderita $G E$ pada bulan berikutnya peneliti menggunakan analisis time series dengan model Winter method.

Dari hasil pemulusan tersebut berhasil meminimalisasi kesalahan dalam peramalan. Dengan rincian penjelasan seperti dalam gambar berikut :

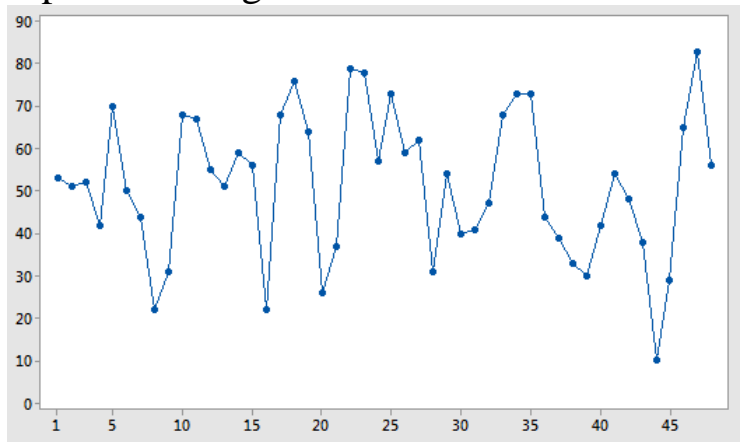

Grafik 4.2 Hasil Pemulusan Jumlah Penderita GEBerdasarkan Jenis Kelamin Laki-lakiRawat InapRSUD Dr. Soetomo Januari 2011 - April 2014

\section{a. Penderita $G E$ perempuan}

Distribusi penderita GE di Instalasi Rawat Inap RSUD Dr. Soetomo Surabaya berdasarkan Jenis Kelamin Perempuan pada bulan Januari 2011 - April 2014 tampak pada tabel dibawah ini:

Tabel 4.5 Jumlah Penderita GE Rawat Inap RSUD Dr. Soetomo

Berdasarkan Jenis Kelamin Perempuan

Bulan Januari 2011 - April 2014

\begin{tabular}{lcccc}
\hline \multicolumn{1}{c}{ Bulan } & 2011 & $\mathbf{2 0 1 2}$ & $\mathbf{2 0 1 3}$ & $\mathbf{2 0 1 4}$ \\
\hline Januari & 53 & 42 & 67 & 38 \\
Februari & 56 & 57 & 57 & 27 \\
Maret & 53 & 50 & 37 & 35 \\
April & 44 & 18 & 30 & 27 \\
Mei & 56 & 58 & 53 & \\
\hline \hline Juni & 47 & 64 & 50 & \\
\hline \hline Juli & 48 & 32 & 31 & \\
Agustus & 24 & 26 & 34 & \\
September & 29 & 39 & 47 & \\
Oktober & 64 & 66 & 60 & \\
November & 65 & 58 & 57 & \\
Desember & 63 & 57 & 28 & \\
\hline
\end{tabular}

\begin{tabular}{ccccc}
\hline Bulan & $\mathbf{2 0 1 1}$ & $\mathbf{2 0 1 2}$ & $\mathbf{2 0 1 3}$ & $\mathbf{2 0 1 4}$ \\
\hline \hline Total & 602 & 567 & 551 & 127 \\
\hline
\end{tabular}

Sumber : Data Unit Rekam Medis Rawat Inap Tahun 2011-2014

Untuk mengetahui analisa pola data pasien berjenis kelamin Perempuan menggunakan autocorrelation function, diketahui bahwa ada unsur musiman. Hal ini tampak pada adanya garis kebawah dan pada titik berikutnya kebawah lagi.

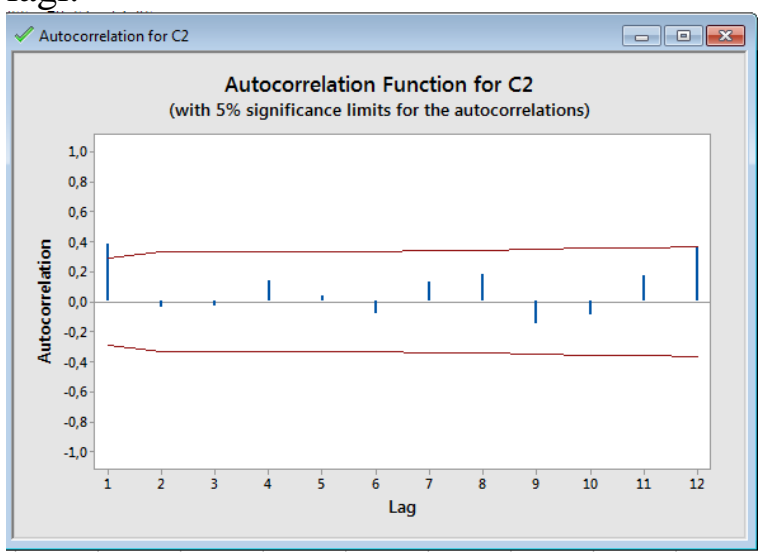

Dari gambar 4.2 dan tabel 4.2 di atas dapat dilihat secara rinci jumlah penderita $G E$ pada tiap bulannya berubah secara tidak teratur, maka perhitungan untuk memproyeksi jumlah penderita $G E$ pada bulan berikutnya peneliti menggunakan analisis time series dengan model Winter method.

Dari hasil pemulusan tersebut berhasil meminimalisasi kesalahan dalam peramalan. Dengan rincian penjelasan seperti dalam gambar berikut :

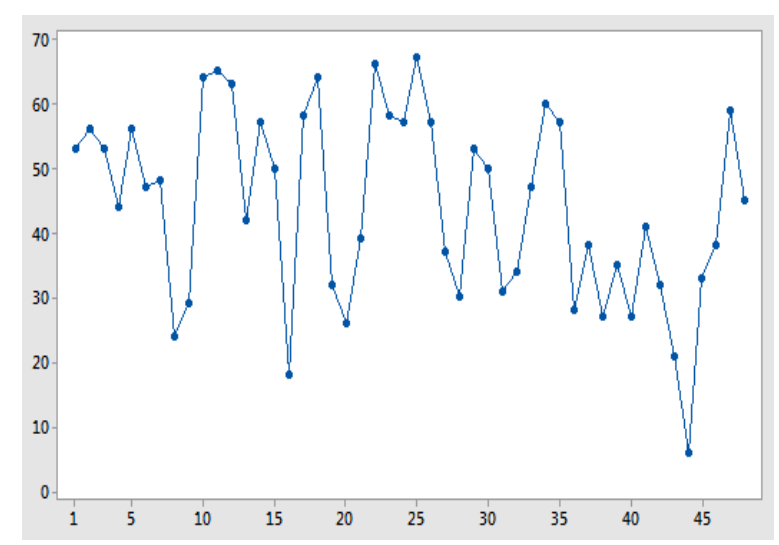


Grafik 4.4 Hasil Pemulusan Dengan

Metode WinterUntuk Data Penderita GE

Rawat Inap RSUD Dr. Soetomo

Berdasarkan Jenis Kelamin Perempuan

\section{Analisis time series total jumlah penderita $G E$ rawat inap}

Distribusi penderita $G E$ di Instalasi Rawat Inap RSUD Dr. Soetomo Surabaya pada bulan Januari 2011 - April 2014 tampak pada tabel dibawah ini:

Tabel 4.8 Jumlah Penderita $G E$ Rawat InapRSUD Dr. Soetomo Januari 2011April 2014

\begin{tabular}{|l|c|c|c|c|}
\hline \multicolumn{1}{|c|}{ Bulan } & $\mathbf{2 0 1 1}$ & $\mathbf{2 0 1 2}$ & $\mathbf{2 0 1 3}$ & $\mathbf{2 0 1 4}$ \\
\hline Januari & 106 & 93 & 140 & 77 \\
\hline Februari & 107 & 116 & 116 & 60 \\
\hline Maret & 105 & 106 & 99 & 65 \\
\hline April & 86 & 40 & 61 & 69 \\
\hline Mei & 126 & 126 & 107 & \\
\hline Juni & 97 & 140 & 90 & \\
\hline Juli & 92 & 96 & 72 & \\
\hline Agustus & 46 & 52 & 81 & \\
\hline September & 60 & 76 & 115 & \\
\hline Oktober & 132 & 145 & 133 & \\
\hline November & 132 & 136 & 130 & \\
\hline Desember & 118 & 114 & 72 & \\
\hline Total & 1207 & 1240 & 1216 & 271 \\
\hline
\end{tabular}

\section{Sumber : Data Unit Rekam Medis} Rawat Inap Tahun 2011-2014

Untuk mengetahui analisa pola data pasien menggunakan autocorrelation function, diketahui bahwa ada unsur musiman. Hal ini tampak pada adanya garis kebawah dan pada titik berikutnya kebawah lagi.

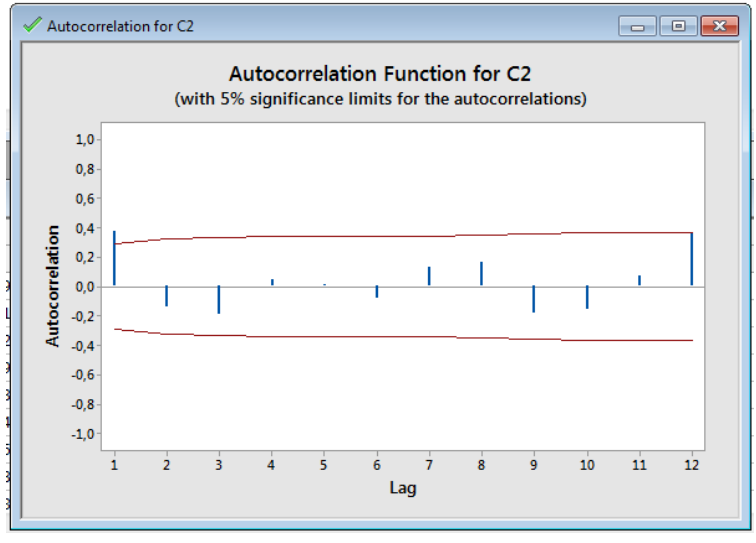

Dari gambar 4.2 dan tabel 4.2 di atas dapat dilihat secara rinci jumlah penderita $G E$ pada tiap bulannya berubah secara tidak teratur, maka perhitungan untuk memproyeksi jumlah penderita $G E$ pada bulan berikutnya peneliti menggunakan analisis time series dengan model Winter method.

Dari hasil pemulusan tersebut berhasil meminimalisasi kesalahan dalam peramalan. Dengan rincian penjelasan seperti dalam gambar berikut :

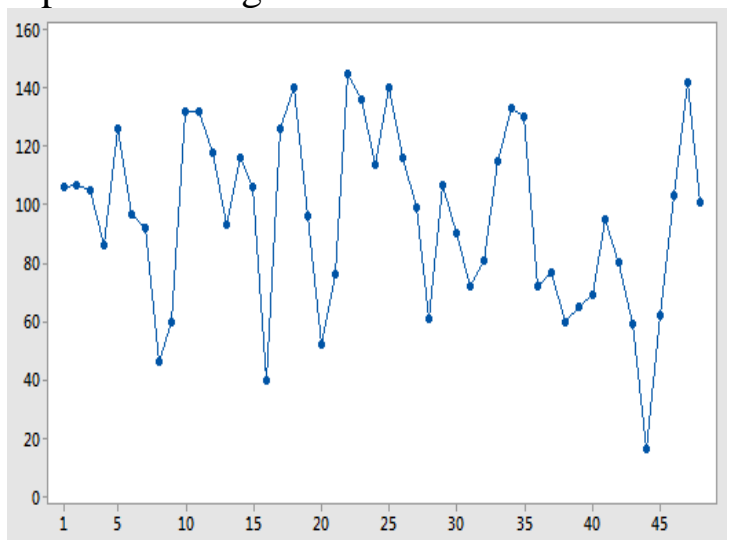

Grafik 4.6 Jumlah penderita $G E$ rawat inap RSUD Dr. SoetomoJanuari 2011-April 2014

Untuk lebih jelasnya, data dalam bentuk grafik diatas dapat dilihat pada setiap titik ordinatnya yang menunjukkan letak daripada kasus penderita $G E$ disetiap bulannya. Didalam rangkaian data diatas terdapat suatu pola musiman, untuk mengurangi kesalahan dalam peramalan yang akan dilakukan maka peneliti menggunakan metode pemulusan eksponensial untuk musiman, karena data tersebut membentuk pola dalam model 
Winter method. Dengan menggunakan beberapa persamaan untuk mengestimasi adanya pengaruh faktor musim dan kemudian dihitung dengan rumus estimasi musiman, supaya dapat dihitung rataratanya dengan indek musiman yang dihaluskan.

Grafik 4.7 Hasil Pemulusan Jumlah Penderita GE Rawat InapRSUD Dr. Soetomo Januari 2011 - April 2014

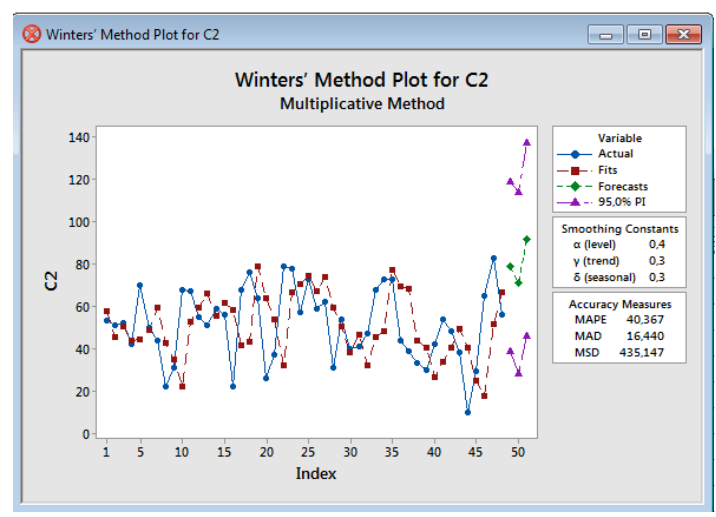

Hasil Peramalan dengan parameter alpha $(\alpha) 0,4$; beta $(\beta) 0,3$ dan gamma 0,3 . Dengan tingkat kesalahan 40.367 MAPE; 16.440 MAD; dan 435.147 MSD.

Grafik 4.7 Hasil Pemulusan Jumlah Penderita GE Rawat InapRSUD Dr. Soetomo Januari 2011 - April 2014

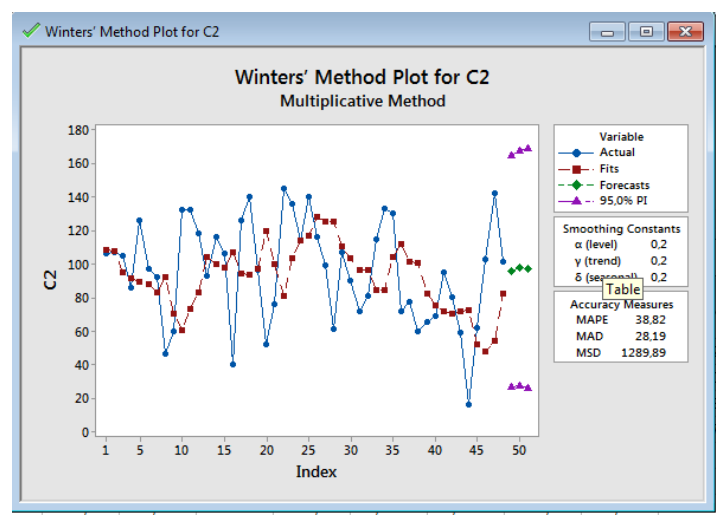

Hasil Peramalan dengan parameter alpha ( $\alpha$ ) 0,2 ; beta $(\beta)$ 0,2 dan gamma 0,2. Dengan tingkat kesalahan 38.82 MAPE; 28.19 MAD; dan 1289.89 MSD.

\begin{tabular}{|c|c|c|c|c|}
\hline Periode & Data & Prediksi & Residual & $\begin{array}{l}\text { Ramalan untuk } 3 \\
\text { periode kedepan }\end{array}$ \\
\hline 1 & 106 & 108,2973658 & $-2,29736582$ & 95,79077302 \\
\hline 2 & 107 & 107,417967 & $-0,417966958$ & 97,61342014 \\
\hline 3 & 105 & 95,27190907 & 9,728090931 & 97,30752931 \\
\hline 4 & 86 & 91,21467559 & $-5,214675593$ & \\
\hline 5 & 126 & 89,1950056 & 36,8049944 & \\
\hline 6 & 97 & 88,10123508 & 8,898764916 & \\
\hline 7 & 92 & 83,23432785 & 8,765672149 & \\
\hline 8 & 46 & 92,05170745 & $-46,05170745$ & \\
\hline 9 & 60 & 70,49232838 & $-10,49232838$ & \\
\hline 10 & 132 & 60,59969196 & 71,40030804 & \\
\hline 11 & 132 & 72,96893877 & 59,03106123 & \\
\hline 12 & 118 & 82,7041979 & 35,2958021 & \\
\hline 13 & 93 & 103,9507931 & $-10,95079309$ & \\
\hline 14 & 116 & 100,0446849 & 15,95531513 & \\
\hline 15 & 106 & 98,09877591 & 7,901224094 & \\
\hline 16 & 40 & 107,2461593 & $-67,24615933$ & \\
\hline 17 & 126 & 94,41408736 & 31,58591264 & \\
\hline 18 & 140 & 93,56957709 & 46,43042291 & \\
\hline 19 & 96 & 97,16172396 & $-1,161723959$ & \\
\hline 20 & 52 & 119,3670564 & $-67,36705645$ & \\
\hline Perio D & ata & Prediksi & Residual & $\begin{array}{l}\text { Ramalan untuk } 3 \\
\text { periode kedepan }\end{array}$ \\
\hline 21 & 76 & 99,80711919 & $-23,80711919$ & \\
\hline 22 & 145 & 80,69774817 & 64,30225183 & \\
\hline 23 & 136 & 103,2273232 & 32,77267676 & \\
\hline 24 & 114 & 113,9783119 & 0,021688078 & \\
\hline 25 & 140 & 116,5255968 & 23,47440324 & \\
\hline 26 & 116 & 128,4029589 & $-12,4029589$ & \\
\hline 27 & 99 & 125,006145 & $-26,006145$ & \\
\hline 28 & 61 & 125,538285 & $-64,53828502$ & \\
\hline 29 & 107 & 110,1506751 & $-3,150675118$ & \\
\hline 30 & 90 & 103,414949 & $-13,41494902$ & \\
\hline 31 & 72 & 96,56801596 & $-24,56801596$ & \\
\hline 32 & 81 & 96,41584379 & $-15,41584379$ & \\
\hline 33 & 115 & 84,45452425 & 30,54547575 & \\
\hline 34 & 133 & 84,48147669 & 48,51852331 & \\
\hline 35 & 130 & 103,75365 & 26,24635 & \\
\hline 36 & 72 & 111,8752694 & $-39,87526941$ & \\
\hline 37 & 77 & 101,2656919 & $-24,26569192$ & \\
\hline 38 & 60 & 100,359381 & $-40,35938096$ & \\
\hline 39 & 65 & 81,96395084 & $-16,96395084$ & \\
\hline 40 & 69 & 75,21252989 & $-6,212529888$ & \\
\hline 41 & 95 & 71,96950197 & 23,03049803 & \\
\hline 42 & 80 & 70,32300033 & 9,6769996672 & \\
\hline 43 & 59 & 71,57586636 & $-12,57586636$ & \\
\hline 44 & 16 & 72,03964167 & $-56,03964167$ & \\
\hline 45 & 62 & 51,66534691 & 10,33465309 & \\
\hline 46 & 103 & 47,95154402 & 55,04845598 & \\
\hline 47 & 142 & 54,29257826 & 87,70742174 & \\
\hline 48 & 101 & 82,29302296 & 18,70697704 & \\
\hline
\end{tabular}




\section{Pembahasan}

Memprediksi jumlah penderita GE rawat inap pada tiga bulan berikutnya berdasarkan data bulanan di Seksi Rekam Medis dari Tahun 2011 sampai Tahun 2014 di Rawat Inap RSUD Dr. Soetomo Surabaya dengan menggunakan Analisis Time Series Metode Winter.

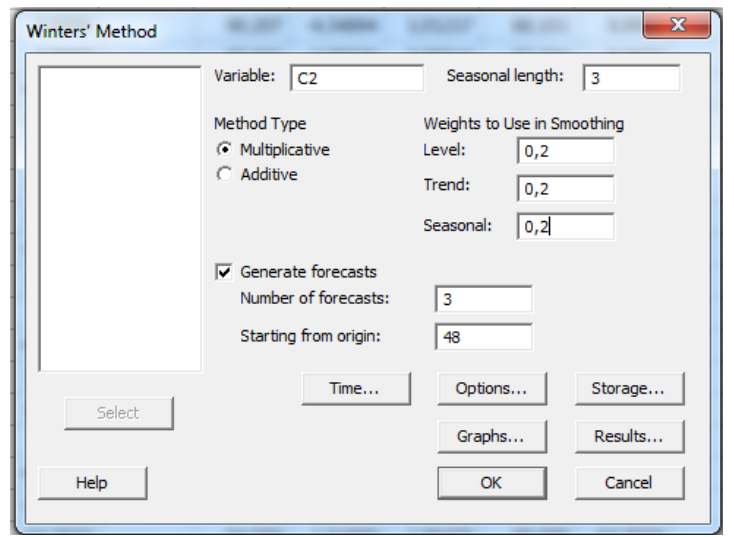

Berdasarkan hasil analisis data diatas dapat diketahui bahwa jumlah penderita $G E$ rawat inap RSUD Dr. Soetomo pada tahun 2011 - 2014 menunjukkan adanya peningkatan dan penurunan, hal ini dapat dilihat pada setiap grafik untuk setiap variabelnya dan dengan menggunakan analisis time series diprediksikan untuk 3 bulan berikutnya jumlah penderita $G E$ mengalami peningkatan pada bulan Mei dan menurun pada Juni, Juli, dan Agustus 2014 dan mulai meningkat lagi pada bulan September, Oktober, dan November 2014 yang dpat dilihat pada grafik 4,8.

Analisis jumlah penderita $G E$ berdasarkan jenis kelamin menunjukkan bahwa jumlah penderita $G E$ jenis kelamin laki-laki lebih banyak dari pada jenis kelamin perempuan yang dapat dilihat pada grafik 4.1. dengan menggunakan analisis time series didapatkan rata-rata jumlah prediksi 3 bulan ke depan, yaitu jenis kelamin laki-laki dan jenis kelamin perempuan mengalami penigkatan jumlah penderita $G E$ pada bulan Mei, dan mengalami penurunan dari bulan Juni, Juli, Agustus dan meningkat pada bulan
September, Oktober, dan Desember 2014 hal ini dapat dilihat pada grafik 4.3 dan 4.5 .

Perhitungan penderita GE berdasarkan jenis kelamin di RSUD Dr. Soetomo, untuk jenis kelamin laki-laki dan jenis perempuan sama-sama analisis time series dengan model Winter Method. Dari jenis kelamin laki-laki mengalami penurunan dan peningkatan jumlah penderita $G E$, begitu juag jenis kelamin perempuan mengalami peningkatan dan penurunan jumlah penderita $G E$.

Dilihat dari total penderita $G E$ perbulan data bulanan di RSUD Dr. Soetomo dari bulan Januari 2011 - April 2014 mengalami peningkatan dan penurunan yang dpaat dilihat pada grafik 4.6, sedangkan untuk bulan Mei mengalami penurunan dan untuk bulan Juni-November tahun 2014 akan diprediksi rata-rata jumlah penderita $G E$ akan mengalami peningkatan dapat dilihat pada grafik 4.8.

Hasil Peramalan jumlah penderita dengan berjenis kelamin perempuan dengan parameter alpha $(\alpha) 0,4$; beta $(\beta)$ 0,3 dan gamma 0,3. Dengan tingkat kesalahan 40.367 MAPE; 16.440 MAD; dan 435.147 MSD.

Hasil Peramalan jumlah penderita dengan berjenis kelamin laki-laki dengan parameter alpha $(\alpha) 0,2$; beta $(\beta) 0,2$ dan gamma 0,2. Dengan tingkat kesalahan 38.82 MAPE; 28.19 MAD; dan 1289.89 MSD.

Peningkatan jumlah penderita $G E$ terjadi karena faktor musim dan kurang adanya program penyuluhan kesehatan pemerintah melalui rumah sakit maupun puskesmas tentang $G E$, dan kurangnya kesadaran masyarakat dalam menjaga kebersihan lingkungan, kebersihan makanan dan minuman yang dikonsumsi setiap harinya, juga kesadaran dalam menerapkan pola hidup sehat. 
PENUTUP

Simpulan

Berdasarkan hasil penelitian dan perhitungan analisis time series dengan menggunakan metode Winterdapat disimpulkan bahwa:

Jumlah penderita $G E$ di RSUD DR. Soetomo tahun 2011-2014 berdasarkan jenis kelamin lebih didominasi oleh lakilaki daripada perempuan. Tahun 20112014 jumlah penderita sering meningkat pada bulan September, Oktober, dan November. Pada tahun 2014 peningkatan jumlah penderita terjadi di bulan September, terjadinya peningkatan tersebut dikarenakan adanya faktor musiman. Jumlah penderita tahun 2011 paling banyak terjadi bulan Oktober sebanyak 132 dan yang paling sedikit pada bulan Agustus sebanyak 46, tahun 2012 jumlah terbanyak terjadi pada bulan Oktober sebanyak 145, paling sedikit pada bulan April sebanyak 40, tahun 2013 paling banyak terjadi di bulan Januari sebanyak 140 dan yang paling sedikit sebanyak $61 \mathrm{di}$ bulan April, dan untuk tahun 2014 kasus terbanyak terjadi pada bulan Januari sebanyak 77 kasus.

Prediksi jumlah penderita $G E$ rawat inap bulan Mei-November

a. Hasil prediksi jumlah penderita $G E$ rawat inap bulan Mei 2014 terjadi peningkatan jumlah penderita menjadi 95 penderita di RSUD Dr. Soetomo.

b. Hasil prediksi jumlah penderita $G E$ rawat inap bulan Juni-Agustus terjadi penurunan jumlah penderita menjadi 80, 59, dan 16 penderita di RSUD Dr. Soetomo.

c. Hasil prediksi jumlah penderita $G E$ rawat inap bulan SeptemberNovember terjadi peningkatan menjadi 62, 103, dan 142 penderita di RSUD DR. Soetomo.

d. Hasil prediksi jumlah penderita $G E$ rawat inap berdasarkan jenis kelamin pada bulan Mei-November 2014. Laki-laki mengalami peningkatan jumlah penderita pada bulan Mei sebanyak 54 penderita. Pada bulan
Juni-Agustus 2014 mengalami penurunan jumlah penderita menjadi 48, 38, dan 10 penderita. Dan pada bulan September-November 2014 mengalami peningkatan jumlah penederita sebanyak 29, 65, dan 83 penderita sebanyak di RSUD Dr. Soetomo.

e. Hasil prediksi jumlah penderita $G E$ rawat inap berdasarkan jenis kelamin pada bulan Mei-November 2014. Perempuan mengalami peningkatan jumlah penderita pada bulan Mei sebanyak 41 penderita. Pada bulan Juni-Agustus 2014 mengalami penurunan jumlah penderita menjadi 32, 21, dan 6 penderita. Dan pada bulan September-November 2014 mengalami peningkatan jumlah penederita sebanyak 33, 38, dan 59 penderita sebanyak di RSUD Dr. Soetomo.

\section{Implikasi dan Saran \\ Implikasi}

Implikasi dari penelitian ini memiliki :

a. Kekuatan : Hasil penelitian ini dapat digunakan untuk upaya perencanaan manajemen RSUD Dr. Soetomo.

b. Kelemahan : Hasil penelitian ini tidak dapat digunakan sebagai acuan dalam jangka waktu panjang karena perlu diadakan evaluasi model Winter pada penderita $G E$.

c. Tantangan : Dalam penelitian ini perlu diadakan evaluasi secara bertahap dengan menambah variabel-variabel penelitian sehingga hasil yang didapatkan agar lebih baik.

d. Peluang : berdasarkan pengembangan variabel penelitian yang baik dapat dilakukan penelitian yang lebih baik lagi.

\section{Saran}

a. Hasil prediksi rata jumlah penderita $G E$ dapat dijadikan upaya perencanaan untuk manajemen RSUD Dr. Soetomo di masa mendatang.

b. Melakukan evaluasi dari model Winter Method secara bertahap guna 
peningkatan kinerja di RSUD Dr. Soetomo.

c. Dengan adanya penambahan data per periode diharapkan pihak manajemen rumah sakit melakukan evaluasi secara rutin menggunakan metode yang sesuai berdasarkan pola data.

\section{DAFTAR PUSTAKA}

Arsyad, Lincolin, 1994. Peramalan Bisnis. Yogyakarta: BPFE-Yogyakarta

Budi, Savitri Citra, 2011. Management Unit Rekam Medis.Yogyakarta: Quantum Sinergi Medis

Depkes RI, 1993. Petunjuk Teknis Penyelenggaraan Rekam Medis/Medical Record Rumah Sakit. Jakarta
Depkes RI, 1997. Pedoman Pengelolaan Rumah Sakit di Indonesia. Jakarta: Direktorat Jenderal Pelayanan Medis

Depkes RI, 2008. Peraturan Menkes RI Nomor: 269/MENKES/PER/III/2008. Jakarta

Notoatmodjo, Soekidjo, 2006. Metode Penelitian Kesehatan. Jakarta: PT.Rineka Cipta

Purbowati, Dina, 2008. Analisis Trend Jumlah Balita Gizi Buruk di Puskesmas Sidotopo Wetan Berdasarkan Berkas Rekam Medis Tahun 2005 - 2008. Karya Tulis Ilmiah. Tidak dipublikasikan. Surabaya: APIKES

Sudjana, 1996.Metoda Statistika.Bandung: Tarsit 